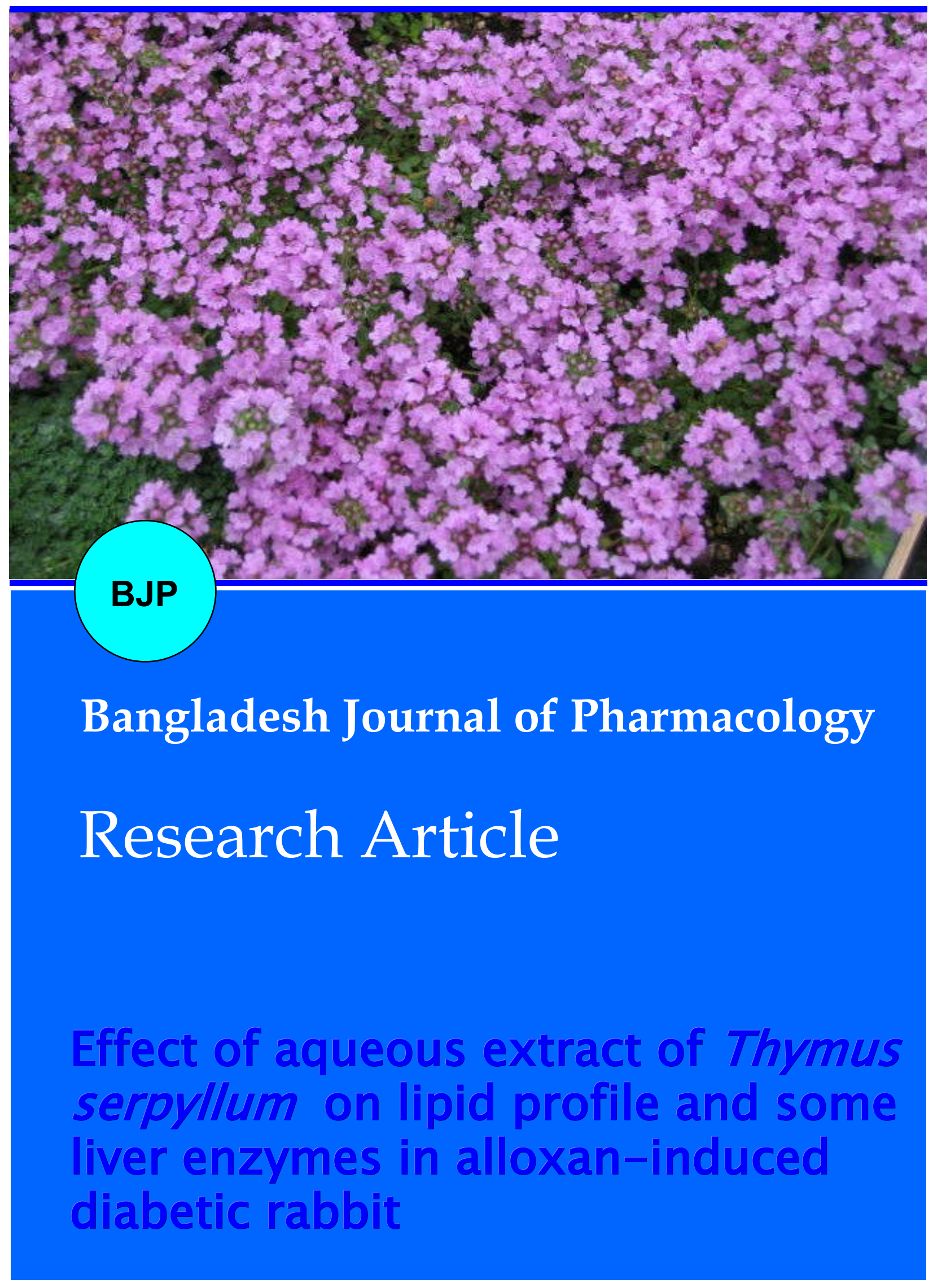


Abstracted/indexed in Academic Search Complete, Asia Journals Online, Bangladesh Journals Online, Biological Abstracts, BIOSIS Previews, CAB Abstracts, Current Abstracts, Directory of Open Access Journals, EMBASE/Excerpta Medica, Google Scholar, HINARI (WHO), International Pharmaceutical Abstracts, Open J-gate, Science Citation Index Expanded, SCOPUS and Social Sciences Citation Index;

ISSN: $1991-0088$

\title{
Effect of aqueous extract of Thymus serpyllum on lipid profile and some liver enzymes in alloxan-induced diabetic rabbit
}

\author{
Alamgeer' and Muhammad Naveed Mushtaq,2 \\ ${ }^{1}$ Department of Pharmacology, Faculty of Pharmacy, University of Sargodha, Sargodha, Pakistan; ${ }^{2}$ Lahore College \\ of Pharmaceutical Sciences, Raiwind Road, Lahore, Pakistan.
}

\begin{tabular}{|c|c|}
\hline \\
\hline \multicolumn{2}{|l|}{ Article Info } \\
\hline Accepted: & 31 December 2016 \\
\hline Available Online: & 3 March 2017 \\
\hline \multicolumn{2}{|c|}{ DOI: 10.3329/bjp.v12i1.29606 } \\
\hline $\begin{array}{l}\text { Cite this article: } \\
\text { Alamgeer, Musht } \\
\text { aqueous extract of } \\
\text { on lipid profile a } \\
\text { zymes in alloxar } \\
\text { rabbit. Bangladesh } \\
\text { 12: } 58-62 \text {. }\end{array}$ & $\begin{array}{l}\text { aq MN. Effect o } \\
\text { f Thymus serpyllum } \\
\text { and some liver en } \\
\text { n-induced diabeti } \\
\text { J Pharmacol. } 2017\end{array}$ \\
\hline
\end{tabular}

\begin{abstract}
The present study was designed to evaluate the effects of aqueous extract of Thymus serpyllum on lipid profile and some liver enzymes level in the diabetic rabbit. Rabbits were made diabetic with a single intravenous injection of alloxan and were divided into groups. Group 1 and 2 served as normal and diabetic control, respectively. Group 3 and 4 were given standard drugs glibenclamide and acarbose respectively while Group 5 was treated with 500 $\mathrm{mg} / \mathrm{kg}$ of extract for 30 days. Blood samples were taken on day 0 and 30 . The extract significantly reduced the level of serum cholesterol, triglyceride, LDLs, VLDLs, alkaline phosphatase and transaminases without affecting the HDLs level. Total cholesterol/HDL-cholesterol ratio was significantly reduced as compared to diabetic control. It is conceivable that T. serpyllum possesses antihyperlipidemic and hepatoprotective effects in diabetic rabbit.
\end{abstract}

\section{Introduction}

Diabetes is usually managed by insulin and oral hypoglycemic drugs but these synthetic agents are associated with serious side effects. Moreover, they fail to significantly control the diabetic complications (Cui et al., 2010; Aslam et al., 2012). This results in exploitation of medicinal plants to treat diabetes and associated complications.

Thymus serpyllum (wild thyme) belongs to the family Labiatae and locally known as Tumuro. In Pakistan, it is found in Gilgit-Baltistan, Kashmir and Jamu. T. serpyllum has been traditionally used in numerous diseases like ailments of the respiratory, digestive and urogenital system. It is given in weak vision, complaints of liver, suppression of urine and menstruation (Qureshi et al., 2007). T. serpyllum has the antidiabetic potential because of its a-glucosidase inhibiting activity (Gholamhoseinian et al., 2008). Moreover, T. serpyllum has been reported to show anti-oxidant activity (Pandey et al., 1996). Many recent studies have proved that anti- oxidants are effective in diabetes and its complications (Naziroglu and Cay, 2001). The plants with both antidiabetic and anti-oxidant activity are considered of better therapeutic value as compared to others for the treatment of diabetes.

In our previous study, the aqueous extract of $T$. serpyllum showed a hypoglycemic effect in diabetic rabbit (Alamgeer et al., 2012). The current study was conducted to investigate the effects of aqueous extract of T. serpyllum on lipid profile and some liver enzyme levels in diabetic rabbits.

\section{Materials and Methods}

\section{Chemicals and drugs}

Alloxan monohydrate was procured from the Sigma Chemicals Co. Glibenclamide and acarbose were obtained from Biorax Pharmaceuticals, Islamabad and Bayer's Pharmaceuticals, Karachi, respectively. Diagnostic kits for biochemical analysis were purchased 
from Merck Chemical Co., Germany.

\section{Plant material}

T. serpyllum plant was collected from the mountains of the village Shikiyote; District Gilgit, Gigit-Baltistan, Pakistan. Plant material was shade dried and powered with a Chinese herbal grinder. The powdered material was stored in well-closed cellophane bags at $4^{\circ} \mathrm{C}$ in the refrigerator. The powdered plant was extracted by the method of cold maceration. The powder was soaked in distilled water for 48 hours with occasional shaking. It was passed through muslin cloth and then filtered through the filter paper. The extract was dried with the help of rotary evaporator (Mushtaq et al., 2016).

\section{Animals used}

Adult rabbits (Oryctolagus cuniculus) of either sex, weighing 1.2-1.5 kg were used. Animals were housed at standard conditions of temperature $\left(23 \pm 12^{\circ} \mathrm{C}\right)$, humidity $(55 \pm 15 \%)$ and 12 hours light and dark cycle. Animals were provided with food and water ad libitum. After an overnight fasting, rabbits were made diabetic with a single intravenous injection of alloxan monohydrate $(150 \mathrm{mg} / \mathrm{kg})$ dissolved in normal saline (Etuk, 2010). After 72 hours of alloxan administration, induction of diabetes was confirmed by measuring the blood glucose level. Rabbits with blood glucose level between 250-300 mg/dL were considered diabetic and were employed for further studies.

\section{Experimental design}

Rabbits were randomly divided into five groups of six animals each. Group 1 and 2 served as untreated control and diabetic control and were administered orally $20 \mathrm{~mL}$ of $2 \%$ aqueous gum tragacanth solution. Group 3 and 4 received orally $600 \mu \mathrm{g} / \mathrm{kg}$ glibenclamide and $3 \mathrm{mg} / \mathrm{kg}$ acarbose, respectively. Group 5 was administered $500 \mathrm{mg} / \mathrm{kg}$ aqueous extract of T. serpyllum (Ramesh and Paugalendi, 2006; Maciejewski et al.,
2001). Treatment was continued for 30 days on daily basis. Serum liver enzymes (alkaline phosphatase, transaminase) and lipid profile of all the rabbits in each group were estimated on day 0 and 30 .

\section{Biochemical analysis}

Blood samples were collected from the ear marginal vein. The serum was separated by centrifugation. The separated serum was preserved in Eppendorf tubes and stored in the refrigerator at below $0^{\circ} \mathrm{C}$. The biochemical tests were performed within 24 hours after collecting the blood.

The level of total serum cholesterol, triglyceride, HDLs, alkaline phosphatase and transaminases were estimated by the enzymatic test kits using Microlab 300 (Merck Chemical Co., Germany). LDLs level was calculated by using formula (Fridewald et al., 1979):

$$
\text { LDL }=\text { Total cholesterol }- \text { HDL }-(\text { Triglyceride/5) }
$$

\section{Statistical analysis}

Values were represented as mean \pm SEM and data were analyzed by ANOVA followed by Turkey's test. A value of $\mathrm{p}<0.05$ was considered significant.

\section{Results}

\section{Effect on liver enzymes}

The aqueous extract of T. serpyllum significantly reduced the level of serum alkaline phosphatase and transaminases in diabetic rabbits treated for 30 days. The standard synthetic drugs, glibenclamide and acarbose also significantly decreased the liver enzyme levels from the start to the end of the month. The levels of serum alkaline phosphatase and transaminases were significantly increased in the rabbits of diabetic control while there was no significant change observed in the normal control rabbits (Table I).

\section{Table I}

Effect of aqueous extract of Thymus serpyllum on liver enzymes levels of the alloxan-induced diabetic rabbit

\begin{tabular}{|c|c|c|c|c|c|c|}
\hline \multirow[t]{2}{*}{ Groups } & \multicolumn{2}{|c|}{$\begin{array}{l}\text { Alanine aminotransferase } \\
\text { (IU/L) }\end{array}$} & \multicolumn{2}{|c|}{$\begin{array}{c}\text { Aspartate aminotransferase } \\
\text { (IU/L) }\end{array}$} & \multicolumn{2}{|c|}{$\begin{array}{l}\text { Alkaline phosphatase } \\
\text { (IU/L) }\end{array}$} \\
\hline & Day 0 & Day 30 & Day 0 & Day 30 & Day 0 & Day 30 \\
\hline Normal control & $\begin{array}{l}45.3 \\
(4.7)\end{array}$ & $\begin{array}{l}47.0 \\
(6.3)\end{array}$ & $\begin{array}{l}53.1 \\
(6.7)\end{array}$ & $\begin{array}{l}49.0 \\
(2.1)\end{array}$ & $\begin{array}{r}92.2 \\
(13.7)\end{array}$ & $\begin{array}{l}86.6 \\
(8.2)\end{array}$ \\
\hline Diabetic control & $\begin{array}{l}84.2 \\
(2.9)\end{array}$ & $\begin{array}{r}134.1 \\
(25.4)^{\mathrm{c}}\end{array}$ & $\begin{array}{l}145.3 \\
(18.0)\end{array}$ & $\begin{array}{r}188.6 \\
(22.8)^{\mathrm{a}}\end{array}$ & $\begin{array}{r}145.3 \\
(18.0)\end{array}$ & $\begin{array}{r}188.6 \\
(22.8)^{\mathrm{a}}\end{array}$ \\
\hline Glibenclamide-treated & $\begin{array}{l}77.3 \\
(3.2)\end{array}$ & $\begin{array}{r}48.5 \\
(4.9)^{\mathrm{b}}\end{array}$ & $\begin{array}{l}113.0 \\
(15.7)\end{array}$ & $\begin{array}{r}69.6 \\
(10.9)^{\mathrm{b}}\end{array}$ & $\begin{array}{r}61.1 \\
(4.2)\end{array}$ & $\begin{array}{r}48.2 \\
(9.8)^{\mathrm{c}}\end{array}$ \\
\hline Acarbose-treated & $\begin{array}{l}79.5 \\
(5.8)\end{array}$ & $\begin{array}{r}47.5 \\
(6.7)^{\mathrm{b}}\end{array}$ & $\begin{array}{r}61.1 \\
(4.2)\end{array}$ & $\begin{array}{r}48.2 \\
(9.8)^{\mathrm{c}}\end{array}$ & $\begin{array}{l}152.0 \\
(42.1)\end{array}$ & $\begin{array}{r}104.5 \\
(22.4)^{\mathrm{b}}\end{array}$ \\
\hline Aqueous extract-treated & $\begin{array}{l}87.3 \\
(6.4)\end{array}$ & $\begin{array}{r}53.3 \\
(6.0)^{\mathrm{b}}\end{array}$ & $\begin{array}{r}75.6 \\
(13.6)\end{array}$ & $\begin{array}{r}45.8 \\
(49.0)^{\mathrm{c}}\end{array}$ & $\begin{array}{l}183.8 \\
(24.4)\end{array}$ & $\begin{array}{r}71.8 \\
(11.0)^{c}\end{array}$ \\
\hline
\end{tabular}

Data are expressed as mean \pm SEM; Significant at $p<0.05$, vs control where $(\mathrm{a})=\mathrm{p}<0.05,(\mathrm{~b})=\mathrm{p}<0.01$ and $(\mathrm{c})=\mathrm{p}<0.001$ 


\section{Effect on lipid profile}

Aqueous extract significantly reduced the triglycerides, cholesterol, LDLs and VLDLs levels in diabetic rabbits. HDLs levels of diabetic treated rabbits were not significantly altered. However, total cholesterol/HDL cholesterol ratio was significantly reduced with the treatment of aqueous extract for 30 days. Glibenclamide and acarbose also significantly reduced all the parameters of lipid profile except HDL. However, these synthetic drugs resulted in significant decrease in the ratio of total cholesterol/HDL cholesterol. Lipid profile parameters except HDLs were significantly increased in the diabetic control group of rabbits. There was no significant change in the lipid profile normal control rabbits (Table II).

\section{Discussion}

The results of the present study show that the aqueous extract of T. serpyllum possesses antihyperlipidemic and hepatoprotective effects in diabetic rabbits. It is well documented that the lipid profile and liver enzyme levels are abnormally changed in diabetes. The levels of alkaline phosphatase and transaminases have been reported to be increased in alloxan-induced diabetic animals. This increase in liver enzymes is suggested due to the cytotoxic effect of alloxan which causes the leakage of the enzymes from hepatic tissues into the blood circulation (Stanely et al., 1999). During diabetes, the other metabolic processes occurring in the liver are disturbed leading to the adverse effects on liver tissues. This is one of the reasons that liver enzymes are increased during the course of diabetes. The increased blood glucose level is associated with the generation of free radical species which damage the liver tissues. The administration of aqueous extract to alloxanized rabbits significantly reduced the hepatic enzyme levels.

T. serpyllum has been reported to possess anti-oxidant effect (Mihailovic-Stanojevic et al., 2013). The protective effect of the extract on liver could be linked to its antioxidant effect as already reported in a previous study. because anti-oxidants have been reported to possess hepatoprotective effect. Glibenclamide and acarbose reduced the liver enzymes by virtue of their hypoglycemic action. So, tight glycemic control by these synthetic drugs is the cause of lowering of liver enzymes. These results are in agreement with the earlier investigation in which the glibenclamide significantly reduced the liver enzyme level in diabetic animals (Rajasekaran et al., 2006).

The results of the present study also show that the aqueous extract of $T$. serpyllum produced a protective effect on the lipid profile which is usually altered during alloxan-induced diabetes. The hyperglycemic condition in the body produces reactive oxygen species (ROS) which causes lipid peroxidation. During diabetes, insulin deficiency leads to various metabolic alterations in the animals which result in increased level of cholesterol, alkaline phosphatase and transaminases (Sharma et al., 2010). In the present investigation, the aqueous extract significantly reduced the levels of serum triglyceride, total cholesterol, LDLs and VLDLs. The results are in accordance with the earlier investigations (Akah et al., 2009, Ajiboye et al., 2015). It is also suggested that the anti-oxidant property of the aqueous extract might neutralize the damage produced by the free radicals and reduced the production of lipid peroxidation products. In the present investigation, the

Table II

Effect of Thymus serpyllum lipid profile in alloxan-induced diabetic rabbit

\begin{tabular}{|c|c|c|c|c|c|c|c|c|c|c|}
\hline Lipid profile & Norn & control & Diab & control & Glibe & $\begin{array}{l}\text { amide } \\
\text { ed }\end{array}$ & Acarb & treated & $\mathrm{Aq}$ & $\begin{array}{l}\text { s extract } \\
\text { ed }\end{array}$ \\
\hline Unit (mg/dL) & Day 0 & Day 30 & Day 0 & Day 30 & Day 0 & Day 30 & Day 0 & Day 30 & Day 0 & Day 30 \\
\hline Triglyceride & $\begin{array}{r}86.1 \\
(12.2)\end{array}$ & $\begin{array}{l}83.8 \\
(6.7)\end{array}$ & $\begin{array}{l}176.1 \\
(29.6)\end{array}$ & $\begin{array}{r}213.6 \\
(32.2)^{\mathrm{b}}\end{array}$ & $\begin{array}{r}107.1 \\
(7.3)\end{array}$ & $\begin{array}{r}58.8 \\
(5.5)^{\mathrm{c}}\end{array}$ & $\begin{array}{r}122.6 \\
(6.2)\end{array}$ & $\begin{array}{r}79.1 \\
(10.8)^{\mathrm{c}}\end{array}$ & $\begin{array}{l}156.6 \\
(20.7)\end{array}$ & $\begin{array}{r}107 \\
(16.2)^{\mathrm{c}}\end{array}$ \\
\hline Cholesterol & $\begin{array}{l}41.6 \\
(3.1)\end{array}$ & $\begin{array}{l}40.3 \\
(3.1)\end{array}$ & $\begin{array}{l}54.5 \\
(4.8)\end{array}$ & $\begin{array}{r}58.3 \\
(5.6)^{\mathrm{a}}\end{array}$ & $\begin{array}{l}60.5 \\
(2.6)\end{array}$ & $\begin{array}{r}42.1 \\
(1.4)^{\mathrm{b}}\end{array}$ & $\begin{array}{l}60.6 \\
(1.8)\end{array}$ & $\begin{array}{r}45.6 \\
(1.7)^{\mathrm{b}}\end{array}$ & $\begin{array}{l}63.0 \\
(2.2)\end{array}$ & $\begin{array}{r}47.3 \\
(2.1)^{\mathrm{b}}\end{array}$ \\
\hline HDLs & $\begin{array}{l}25.0 \\
(2.7)\end{array}$ & $\begin{array}{l}23.3 \\
(2.2)\end{array}$ & $\begin{array}{l}12.6 \\
(1.8)\end{array}$ & $\begin{array}{l}10.5 \\
(1.8)\end{array}$ & $\begin{array}{l}12.0 \\
(1.0)\end{array}$ & $\begin{array}{l}15.8 \\
(0.1)\end{array}$ & $\begin{array}{l}12.3 \\
(1.3)\end{array}$ & $\begin{array}{l}14.8 \\
(1.4)\end{array}$ & $\begin{array}{l}12.5 \\
(0.9)\end{array}$ & $\begin{array}{l}14.8 \\
(1.4)\end{array}$ \\
\hline LDLs & $\begin{array}{r}4.4 \\
(0.6)\end{array}$ & $\begin{array}{r}4.5 \\
(0.5)\end{array}$ & $\begin{array}{l}12.6 \\
(2.9)\end{array}$ & $\begin{array}{r}17.1 \\
(3.1)^{\mathrm{a}}\end{array}$ & $\begin{array}{l}28.6 \\
(2.5)\end{array}$ & $\begin{array}{c}14.4 \\
(1.0)^{\mathrm{b}}\end{array}$ & $\begin{array}{l}23.7 \\
(1.9)\end{array}$ & $\begin{array}{r}14.4 \\
(1.8)^{\mathrm{b}}\end{array}$ & $\begin{array}{l}19.6 \\
(2.4)\end{array}$ & $\begin{array}{r}11.1 \\
(1.7)^{\mathrm{b}}\end{array}$ \\
\hline VLDLs & $\begin{array}{l}17.2 \\
(2.4)\end{array}$ & $\begin{array}{l}16.8 \\
(1.3)\end{array}$ & $\begin{array}{l}35.2 \\
(5.9)\end{array}$ & $\begin{array}{r}42.7 \\
(6.4)^{\mathrm{b}}\end{array}$ & $\begin{array}{l}21.4 \\
(1.4)\end{array}$ & $\begin{array}{r}11.7 \\
(1.1)^{\mathrm{b}}\end{array}$ & $\begin{array}{l}25.2 \\
(1.5)\end{array}$ & $\begin{array}{r}15.7 \\
(2.1)^{\mathrm{b}}\end{array}$ & $\begin{array}{l}31.3 \\
(4.1)\end{array}$ & $\begin{array}{r}21.3 \\
(3.2)^{\mathrm{b}}\end{array}$ \\
\hline T.C/HDL.C & $\begin{array}{r}1.9 \\
(0.2)\end{array}$ & $\begin{array}{r}2.0 \\
(0.2)\end{array}$ & $\begin{array}{r}5.2 \\
(0.6)\end{array}$ & $\begin{array}{r}7.8 \\
(1.4)^{\mathrm{b}}\end{array}$ & $\begin{array}{r}5.1 \\
(0.4)\end{array}$ & $\begin{array}{r}2.7 \\
(0.1)^{\mathrm{b}}\end{array}$ & $\begin{array}{r}5.6 \\
(0.5)\end{array}$ & $\begin{array}{r}3.3 \\
(0.3)^{\mathrm{b}}\end{array}$ & $\begin{array}{r}4.5 \\
(0.9)\end{array}$ & $\begin{array}{r}3.3 \\
(0.4)^{\mathrm{b}}\end{array}$ \\
\hline
\end{tabular}

Data are expressed as mean \pm SEM significant atp $<0.05$, vs control where $(a)=p<0.05,(b)=p<0.01$ and $(c)=p<0.001$ 
standard drugs glibenclamide and acarbose also produced reduction in the lipid profile of diabetic rabbits. In a previous study, glibenclamide alone and in combination with shilagit reduced lipid profile (Trivedi et al., 2004). It has also been reported that acarbose reduces the some parameters of lipid profile (Mughal et al., 2000). The glycemic control is the major determinant of the total cholesterol and triglyceride concentration. So, the glycemic control in the diabetic treated rabbits by these drugs could be the major cause of the reduction in these parameters.

\section{Conclusion}

The aqueous extract of T. serpyllum possess significant and consistent hypolipidemic and hepatoprotective effects in alloxan-induced diabetic rabbits.

\section{Ethical Issue}

The study protocol was approved by the local ethical committee.

\section{Conflict of Interest}

All authors have completed the ICMJE uniform disclosure form and declare no support from any organization for the submitted work.

\section{Acknowledgement}

Authors are thankful to Dr. Shair Wali, Assistant Professor of Botany, Karakoram International University, Gilgit-Baltistan for identification of the plant.

\section{References}

Ahmad M, Mahmood Q, GulzarK, Akhtar MS, Saleem M, Qadir MI. Antihyperlipidemic and hepatoprotective activity of Dodonae aviscosa leaves extracts in alloxan-induced diabetic rabbits (Oryctolagus cuniculus). Pakistan Vet J. 2012; 32: 50-54.

Ajiboye BO, Muhammad NO, Oloyede HOB. Serum lipid profile of alloxan-induced diabetic rats fed Triticum aestivumbased diet. Int J Trop Dis Health. 2015; 5: 260-68.

Akah PA, Alemji JA, Salawu OA, Okoye TC, Offiah NV. Effects of Vernonia amygdalina on biochemical and hematological parameters in diabetic rats. Asian J Med Sci. 2009; 1: 108-13.

Akhtar MS, Nadeem M, Rashid HU, Bashir S. Hypoglycaemic activity of different fractions of Berberis aristata root-bark in normal and alloxan diabetic rabbits. Can J App Sci. 2011; 1: 16-28.
Alamgeer, Mushtaq MN, Bashir S, Rashid M, Malik MNH, Ghumman SA, Irfan HM, Akram M, Khan AQ, Rashid HU. Hypoglycemic and hematological effects of aqueous extract of Thymus serpyllum Linn. in alloxan-induced diabetic rabbits. Afri J Pharm Pharmacol. 2012; 6: 2845-50.

Amin IM. Hypoglycemic effects in response to Abelmoshus esculentus treatment: A research framework using STZinduced diabetic rats. Int J Biosci Biochem Bioinf. 2011; 1: 6367.

Aslam N, Sheikh MA, Rehman KU, Nawaz H. Biochemical profile indicative of insulin resistance in nondiabetic and diabetic cardiovascular patients. Int J Agric Biol. 2012; 14: 126-30.

Cui G, Jing L, Feng Q, Xiao Y, Putheti Y. Antihyperglycemic activity of polysaccharide fraction from Lycium barbarum. Afr J Biomed Res. 2010; 13: 55-59.

Etuk EU. Animals models for studying diabetes mellitus. Agri Biol J N Am. 2010; 1: 130-34.

Eze ED, Dawud FA, Zainab AA, Jimoh A, Malgwi IS, Isa AS. Preliminary studies of effects of vitamin $C$ and zinc on some liver enzymes in alloxan-induced diabetic Wistar Rats. Asian J Med Sci. 2012; 4: 17-22.

Fridewald WT, Levy RI, Sloane-Stanley GD. Estimation of concentration of low density cholesterol in plasma without use of preparative ultracentrifuge. Clin Chem. 1979; 18: 499508.

Gholamhoseinian A, Fallah H, Sharifi-far F, Mirtajaddini M. The inhibitory effect of some Iranian plants extracts on the alpha glucosidase. Iran J Basic Med Sci. 2008; 11: 1-9.

Maciejewski R, Rucinski P, Burski K, Figura T. Changes in glucose, cholesterol and serum lipid fraction levels in experimental diabetes. Ann Univ Mariae Curie Sklodowska. 2001; 56: 363-68.

Mihailovic-Stanojevic N, Belscak-Cvitanovic A, GrujicMilanovic J, Ivanov M, Jovovi DJ, Bugarski D, Miloradovic Z. Anti-oxidant and antihypertensive activity of extract from Thymus serpyllum L. in experimental hypertension. Plant Foods Hum Nutr. 2013; 68: 235-40.

Mughal MA, Memon MY, Zardari MK, Tanwani RK, Ali M. Effect of acarbose on glycemic control, serum lipids and lipoproteins in type 2 diabetes. Pakistan J Med Assoc. 2000; 50: $152-56$

Mushtaq MN, Akhtar MS, Alamgeer, Ahmad T, Khan HU, Maheen S, Ahsan H, Naz H, Asif H, Younis W, Tabassum N. Evaluation of antihypertensive activity of Sonchus asper L. in rats. Acta Pol Pharm Drug Res. 2016; 73: 425-31.

Mushtaq MN, Akhtar MS, Alamgeer. Blood pressure lowering effect of Pennisetum glaucum in rats. Bangladesh J Pharmacol. 2015; 10: 494-99.

Naziroglu M, Cay M. Protective role of intraperitoneally administered vitamin $\mathrm{E}$ and selenium on the anti-oxidative defense mechanisms in rats with diabetes induced by streptozotocin. Biol Trace Elem Res. 2001; 79: 149-59.

Pandey MC, Sharma JR, Dikshit AJ. Antifungal evaluation of the essential oil of Cymbopogon pendulus. Flavour Frag J. 1996; 
11: 257-60.

Qureshi RA, Ghufran MA, Gilani SA, Sultana K, Ashraf M. Ethnobotanical studies of selected medicinal plants of Sudhan Gali and Ganga Chotti Hills, District, Azad Kashmir. Pakistan J Bot. 2007; 39: 2275-83.

Rajasekaran S, Ravi K, Sivagnanam K, Subramanian S. Beneficial effects of Aloe vera leaf gel extract on lipid profile status in rats with streptozotocin diabetes. Clin Exp Pharmacol Physiol. 2006; 33: 232-37.

Ramesh B, Paugalendi KV. Antihyperglycemic effect of umbelliferone in streptozotocin-diabetic rats. J Med Food.
2006; 9: 562-66.

Sharma VK, Kumar S, Patel HJ, Hugar S. Hypoglycemic activity of Ficus glomerata in alloxan-induced diabetic rats. Int J Pharm Sci Rev Res. 2010; 1: 18-22.

Stanely P, Prince PM, Menon V. Hypoglycemic and other related actions of Tinospora cordifolia roots in alloxaninduced diabetic rats. J Ethnopharmacol. 1999; 70: 9-15.

Trivedi NA, Mazumdar B, Bhatt JD, Hemavathi KG. Effect of shilagit on blood glucose and lipid profile in alloxaninduced diabetic rats. Indian J Pharmacol. 2004; 36: 373-76.

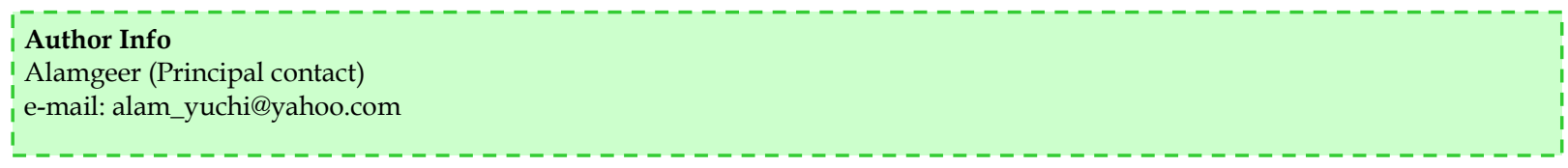




\section{Your feedback about this paper}

1. Number of times you have read this paper 0

2. Number of times you have seen the video clip 0

3. Quality of paper Click

4. Your comments

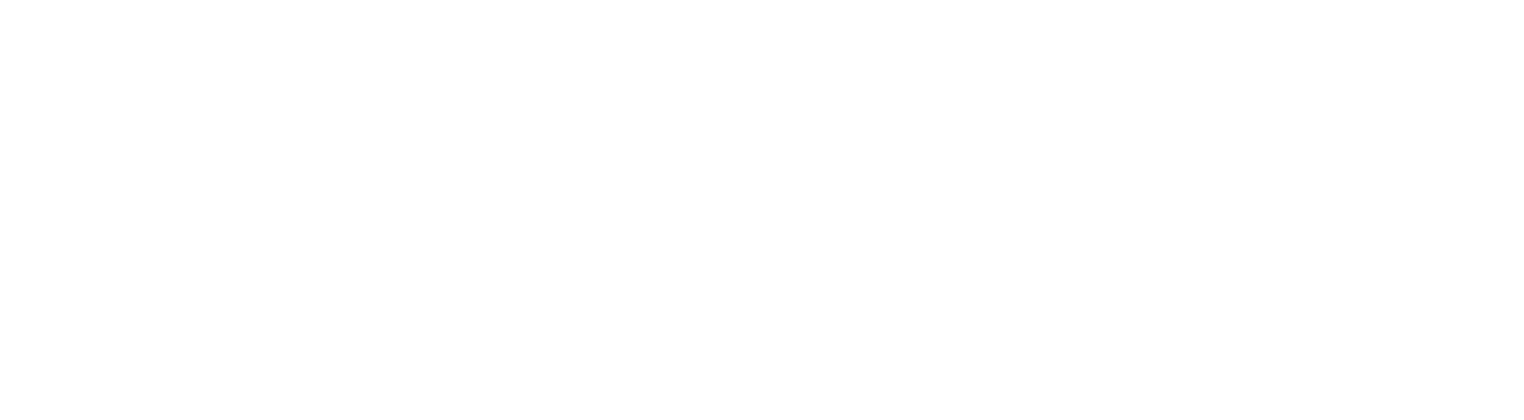

